돈분, 계분 그리고 혼합물에 대한 연소특성

정영진 $^{\dagger}$

강원대학교 소방방재공학과

(2013년 7월 8일 접수, 2013년 7월 23일 심사, 2013년 8월 22일 채택)

\title{
Combustion Characteristics of Swine Manure, Poultry Manure and Mixtures
}

\author{
Yeong-Jin Chung ${ }^{\dagger}$ \\ Department of Fire Protection Engineering, Kangwon National University, Gangwon-do 245-710, Korea \\ (Received July 8, 2013; Revised July 23, 2013; Accepted August 22, 2013)
}

\begin{abstract}
본 연구에서는 자원 재활용-에너지에 바탕을 둔 돈분, 계분, 혼합물의 연소특성에 대하여 고찰하였다. 시험편은 건조 오븐을 이용하여 항량까지 건조시킨 후에, 콘칼로리미터(ISO 5660-1)를 이용하여 연소성질을 시험하였다. 그 결과 돈 분의 최대유효연소열 $(78.72 \mathrm{MJ} / \mathrm{kg})$ 은 계분 $(69.41 \mathrm{MJ} / \mathrm{kg})$ 과 비교하여 탄화수소의 많은 양 때문에 비교적 증가했다. 또한 돈분의 $\mathrm{CO}_{2}$ 발생속도 $(0.1959 \mathrm{~g} / \mathrm{s})$ 와 총연기발생률 $\left(419 \mathrm{~m}^{2} / \mathrm{m}^{2}\right)$ 도 각각에 대하여 계분보다 증가하였다. 반면에 계분의 $\mathrm{CO}$ 발생량 $(0.0996 \mathrm{~kg} / \mathrm{kg})$ 과 CO 발생속도 $(0.0034 \mathrm{~g} / \mathrm{s})$ 는 계분이 함유하고 있는 많은 무기물 함량 때문에 각각 돈분보다 높았다. 따라서 높은 연소 에너지는 탄화수소 함량에 의존하여 발생되는 것으로 판단된다.

In this work, the combustive properties of the swine manure, poultry manure, and mixtures based on the resource recycling-energy were investigated. After the specimens were dried to a constant weight by dry oven, combustive properties were tested by the cone calorimeter (ISO 5660-1). It was found that the peak effective heat of combustion (PEHC) in the swine manure $(78.72 \mathrm{MJ} / \mathrm{kg}$ ) has risen due to more amount of the hydrocabon compared with poultry manure $(69.41 \mathrm{MJ} / \mathrm{kg})$, also the swine manure increased both of the higher $\mathrm{CO}_{2}$ production rate $(0.1959 \mathrm{~g} / \mathrm{s})$ and total smoke release rate (THRR) $\left(419 \mathrm{~m}^{2} / \mathrm{m}^{2}\right)$ than those of the poultry manure. However, both of the CO production release $(0.0996 \mathrm{~kg} / \mathrm{kg})$ and CO production rate $(0034 \mathrm{~g} / \mathrm{s})$ in the poultry manure increased due to more amount of the inorganic contents compared with swine manure. Thus, the high combustion energy is expected to generate depend on the hydrocarbon content.
\end{abstract}

Keywords: combustive properties, peak effective heat of combustion, CO production rate, total smoke release rate

\section{1. 서 론}

우리나라의 경우 2005년 온실가스 총 배출량은 5.9 억 ton으로 전세 계 배출량의 $1.7 \%$ 를 차지하고 있으며 현재 1990 년과 대비하여 배출 량이 $98.7 \%$ 증가하였고, 획기적인 감축노력이 없을 경우 2020년 배출 량은 2005년 대비 $37.7 \%$ 증가할 것이라고 보고된 바 있다[1]. 이와 관련 하여 국내에서도 지구 온난화에 대비하여 전 세계 온실가스의 배출량 중 $18 \%$ 를 차지하는 축산폐기물 처리에 관련된 법률을 제정하여 규제 를 강화하고 있으나, 경제성장과 더불어 축산업이 동반성장 하면서 가축분뇨의 발생량이 매년 증가하는 추세로 이에 대한 대책이 시급한 실정이다.

이러한 축산분뇨 처리와 관련하여 미국, 유럽을 비롯한 선진국에서 는 축산분뇨 에너지화로 재생에너지의 일정 부분을 담당하고 있으며,

† Corresponding Author: Kangwon National University

Department of Fire Protection Engineering

Samcheok-city, Gangwon-do 245-710, Korea

Tel: +82-33-540-3121 e-mail: yjchung@kangwon.ac.kr

pISSN: 1225-0112@2013 The Korean Society of Industrial and Engineering Chemistry. All rights reserved.
환경오염 배출이 없는 청정에너지로서 그 중요성이 날로 부각되고 있 다. 그러나 국내의 경우에는 선진국에 비해 신재생에너지가 차지하는 비중은 현저히 낮은 실정이다. 이에 농림식품부는 가축분뇨 자원화 사업을 저탄소 녹색성장의 중심사업으로 발전시키고 기존처리 시설의 내실 있는 고려와 퇴·액비 품질향상, 효율적 관리를 위한 민간기구 추진 등 축분뇨 자원화 처리기반 시설의 구축에 대해 발표하였다[2].

일찌기 이에 대한 선행 연구로 Boss는 다중 목적에 의한 지속 가능 한 도시-환경 관리를 연구하였고[3], 국내에서는 국내여건에 적합한 가축분뇨 바이오가스 생산 최적시스템 연구를 하였고[4] 정부에서는 가축분뇨 자원화 및 효율적인 관리방안을 위해 노력해왔다[5]. 이어서 자원순환형 가축분뇨 에너지화 방안 등을 지속적으로 연구하여 왔다 [6].

현재 가축분뇨의 에너지화 과정 중 바이오가스와 퇴 - 액비를 이용 한 에너지화에 대한 연구들은 보고된 바 있으나, 가축 폐기물의 연소 특성에 대한 연구는 미비한 실정으로 부가적인 연구가 필요하다. 이 들의 연소특성은 열방출률, 연소전파 및 연소가스의 유해성 등을 측 정하여 평가할 수 있다. 이들 중 가장 중요한 평가요소 중의 하나는 가연물이 연소되는 동안에 발생되는 열방출률(heat release rate)이다. 많은 기술들이 발전되어 왔는데 그중의 하나가 콘칼로리미터(cone 
Table 1. Elementary Analysis of the Swine Manure, Poultry Manure, and Mixture

\begin{tabular}{ccccc}
\hline Sample & $\mathrm{C}(\mathrm{wt} \%)$ & $\mathrm{H}(\mathrm{wt} \%)$ & $\mathrm{S}(\mathrm{wt} \%)$ & $\mathrm{N}(\mathrm{wt} \%)$ \\
\hline Swine & 42.57 & 6.58 & 1.01 & 3.63 \\
Poultry & 29.62 & 4.25 & 0.00 & 3.98 \\
Mixture & 39.79 & 6.09 & 0.00 & 3.57 \\
\hline
\end{tabular}

Table 2. Analytical Results of the Swine Manure, Poultry Manure, and Mixture by XRF

\begin{tabular}{ccccccccc}
\hline Sample & $\mathrm{CaO}(\mathrm{wt} \%)$ & $\mathrm{P}_{2} \mathrm{O}_{5}(\mathrm{wt} \%)$ & $\mathrm{ZnO}(\mathrm{wt} \%)$ & $\mathrm{K}_{2} \mathrm{O}(\mathrm{wt} \%)$ & $\mathrm{SO}_{3}(\mathrm{wt} \%)$ & $\mathrm{MgO}(\mathrm{wt} \%)$ & $\mathrm{F}_{2} \mathrm{O}_{3}(\mathrm{wt} \%)$ & $\mathrm{Others}_{(\mathrm{wt} \%)}$ \\
\hline Swine & 24.80 & 21.50 & 13.40 & 12.90 & 5.82 & 5.58 & 4.94 \\
Poultry & 53.10 & 12.90 & 0.41 & 12.70 & 5.68 & 4.37 & 1.06 \\
Mixture & 33.90 & 18.80 & 10.30 & 11.30 & 6.76 & 5.19 & 4.20 & 9.21 \\
\hline
\end{tabular}

Table 3. Specifications of the Swine Manure, Poultry Manure, and Mixture

\begin{tabular}{ccccc}
\hline Sample & Thickness $(\mathrm{mm})$ & Mass $(\mathrm{g})$ & Inorganic content $(\mathrm{wt} \%)$ & Density $\left(\mathrm{g} / \mathrm{cm}^{3}\right)$ \\
\hline Swine & 10.0 & 28.6 & 8.3 & 0.286 \\
Poultry & 10.0 & 34.0 & 41.0 & 0.340 \\
Mixture & 10.0 & 29.2 & 29.4 & 0.292 \\
\hline
\end{tabular}

calorimeter)법이다[7]. 콘칼로리미터법에 의한 열방출률 측정은 대부 분의 유기재료가 연소 중에 산소 $1 \mathrm{~kg}$ 이 소비되면 약 $13.1 \mathrm{MJ}$ 의 열이 방출되는 산소 소비 원리를 바탕으로 하고 있다[8].

따라서 본 연구의 목적은 우리나라 가축분뇨 중 돈분, 계분, 이들 혼합물의 연소특성을 콘칼로리미터(ISO 5660-1)[9]를 이용하여 열방 출률, 질량감소율, 유효연소열, 일산화탄소, 이산화탄소, 총연기발생률 등을 측정하여 분석하였다.

\section{2. 실 험}

\section{1. 재료}

전처리 과정을 거친 돈분, 계분, 혼합물(돈분 : 계분 $=1: 1$, 체적비) 의 3 종 가축분뇨 시료는 $100{ }^{\circ} \mathrm{C}$ 의 건조 오븐에서 건조시키면서 $24 \mathrm{~h}$ 마다 측정했을 때 무게가 $0.1 \mathrm{wt} \%$ 또는 $0.1 \mathrm{~g}$ 이상 차이가 나지 않았을 때 항량으로 하였다. 본 연구에서는 Sam Woo Scientific사의 Mechnical circulation oven을 이용하여 $100{ }^{\circ} \mathrm{C}$ 에서 $12 \mathrm{~h}$ 후에 무게의 변화가 둔 화되어, 건조 후 $4 \mathrm{~h}$ 간격으로 $12 \mathrm{~h}$ 동안만 측정하였다[10].

시료의 원소분석은 Rigaku사의 X-Ray Fluorescence Spectrometer (XRF, model : ZSX-100e)을 사용하여 측정된 값을 사용하였다. Table 1,2 는 돈분, 계분, 혼합물 각각의 원소분석을 나타내었다[10]. 시편의 체적밀도는 시험하기 전에 전술한 절차에 의하여 건조된 시료의 부피 와 무게를 측정하여 Table 3에 계산하였다.

\section{2. 콘칼로리미터 시험}

Dual cone calorimeter (Fire Testing Technology)에 의한 열방출률 측정[8]은 설정한 복사열에 노출된 시편이 착화되어 연소될 때 연소 생성물 흐름속의 산소 농도와 유속으로부터 유도된 산소 소비량을 측 정하여 평가하였다. 재료의 연소로 인한 열방출률과 단위면적당 열방 출률은 식 (1)과 (2)에 의하여 계산된다.

$$
\dot{q}(t)=\left(\triangle h_{c} / r_{0}\right)(1.10) C \sqrt{\frac{\triangle P}{T_{e}}} \frac{X_{O 2}^{o}-X_{O 2}}{1.105-1.5 X_{O 2}}
$$

$$
q_{A}(t)=\dot{Q} / A=\dot{q}(t) / A_{S}
$$

이때 $\mathrm{q}_{\mathrm{A}}(\mathrm{t})$ : 단위면적당 열방출률 $\left(\mathrm{kW} / \mathrm{m}^{2}\right), \dot{q}(\mathrm{t})$ : 열방출률(열방출 속도) $(\mathrm{kW}), \mathrm{A}_{\mathrm{s}}$ : 실험체의 표면적 $\left(\mathrm{m}^{2}\right), \Delta \mathrm{h}_{\mathrm{c}}$ : 순수연소열 $(\mathrm{kJ} / \mathrm{kg})$, $\mathrm{r}_{\mathrm{o}}$ : 화학양론적 산소 대 연료 질량비, $\mathrm{C}$ : 산소소비량 보정상수 $\left(\mathrm{m}^{1 / 2} \mathrm{~kg}^{1 / 2} \mathrm{~K}^{1 / 2}\right), \Delta \mathrm{P}$ : 오리피스의 압력차 $(\mathrm{Pa}), \mathrm{T}_{\mathrm{e}}$ : 오리피스에서의 기체의 절대온도 $(\mathrm{K}), \mathrm{X}_{\mathrm{O} 2}: \mathrm{O}_{2}$ 의 몰분율에 대한 산소분석기 눈금 판독 값, $\mathrm{X}_{\mathrm{O} 2}^{\mathrm{O}}$ : 산소분석기 눈금의 초기 값이다.

사용한 시험편의 두께는 $10 \mathrm{~mm}$, 크기는 $100 \times 100 \mathrm{~mm}( \pm 2)$ 의 규 격으로 제작하였으며, 시험조건은 온도 $23 \pm 2{ }^{\circ} \mathrm{C}$, 상대습도 $50 \pm 5 \%$ 에서 항량이 될 때까지 유지한 다음 알루미늄 호일로 비노출면을 감 싼다. 시험에 앞서 콘히터의 열량이 설정값 $\pm 2 \%$ 이내, 산소분석기의 산소농도가 $20.95 \pm 0.01 \%$ 가 되도록 교정하고 배출유량을 $0.024 \pm$ $0.002 \mathrm{~m}^{3} / \mathrm{s}$ 로 설정하였다.

시험편은 단열재인 저밀도 유리섬유를 이용하여 높이를 조절하였 으며, 시편 홀더로의 열손실을 감소시키기 위하여 전도도가 낮은 고 밀도 세라믹판 재료로 절연시켰다. 시편홀더는 수평방향으로 위치시 켰다. 시편의 체적밀도는 시험하기 전에 부피와 무게를 측정하여 계산 하였다. 연소시험은 지속적인 불꽃 연소가 시작된 때부터 $30 \mathrm{~min}$ 경과 후에 종료하였으며, 추가로 $2 \mathrm{~min}$ 간의 데이터 수집시간을 부여하였다.

본 연구에서 선정된 시험편은 콘칼로리미터에 수평으로 설치하고 외부 점화장치를 부착한 상태로 $50 \mathrm{~kW} / \mathrm{m}^{2}$ 외부 열유 속에 수십분 동안 노출시켜 착화되는 시간과 착화된 시료로부터 열방출률 및 연기 관련 지수를 구하였다.

\section{3. 결과 및 고찰}

\section{1. 시험편의 열방출 성질}

가연성 물질이 연소될 때의 에너지 방출 속도, 연기생성, 가스 독성은 가연물의 종류, 밀도, 수분함량, 열침투성 및 열적특성 등에 따라 결정 된다[11-13]. 시험하는 동안에 측정되는 주 연소특성은 열방출률이다. 
Table 4. Combustive Properties of the Specimens of the Swine Manure, Poultry Manure, and Mixture

\begin{tabular}{|c|c|c|c|c|}
\hline Specimen & $\operatorname{HRR}_{\text {peak }}^{\mathrm{a}}\left(\mathrm{kW} / \mathrm{m}^{2}\right)$ & $\operatorname{MLR}_{\text {peak }}^{\mathrm{b}}(\mathrm{g} / \mathrm{s})$ & $\mathrm{EHC}_{\text {peak }}^{\mathrm{c}}(\mathrm{MJ} / \mathrm{kg})$ & $\operatorname{THRR}^{\mathrm{d}}\left(\mathrm{MJ} / \mathrm{m}^{2}\right)$ \\
\hline Swine & 256.82 & 0.173 & 78.72 & 60.8 \\
\hline Poultery & 147.95 & 0.132 & 69.41 & 39.7 \\
\hline Specimen & $\mathrm{CO}_{\text {mean }}(\mathrm{kg} / \mathrm{kg})$ & $\mathrm{CO}_{2}$ mean $(\mathrm{kg} / \mathrm{kg})$ & $\mathrm{CO} / \mathrm{CO}_{2}$ & $\operatorname{TSRR}^{\mathrm{e}}\left(\mathrm{m}^{2} / \mathrm{m}^{2}\right)$ \\
\hline Swine & 0.0827 & 2.11 & 0.0391 & 419.0 \\
\hline
\end{tabular}

${ }^{\mathrm{a}}$ Peak heat release rate, ${ }^{\mathrm{b}}$ peak mass loss rate, ${ }^{\mathrm{c}}$ peak effective heat of combustion, ${ }^{\mathrm{d}}$ total heat release rate, ${ }^{\mathrm{e}}$ total smoke release rate

이것은 시료 표면적당 발생한 순간적인 열량의 크기로 표현되며, 재 료의 연소 위험성을 가장 잘 나타낼 수가 있는 요소로서, 연소모델링 을 위한 중요한 측정값이다[14,15]. Table 4는 측정된 시험편들의 연 소성질을 나타내었다.

Tables 1,2 의 시험편 조성에 대한 $50 \mathrm{~kW} / \mathrm{m}^{2}$ 의 외부 열원에서 시험 한 돈분 시험편의 최대열방출률(peak heat release rate, PHRR)은 $256.82 \mathrm{~kW} / \mathrm{m}^{2}$ 로 측정되었다. 이에 비하여 계분의 최대열방출률은 $147.95 \mathrm{~kW} / \mathrm{m}^{2}$ 으로 비교적 낮게 나타났다. 또한 돈분과 계분을 체적 비로 1 : 1 혼합한 혼합물의 최대열방출률은 $206.18 \mathrm{~kW} / \mathrm{m}^{2}$ 로 측정되 었다. 이와 같이 돈분의 최대열방출률이 계분의 최대열방출률보다 비 교적 높게 나타난 것은 돈분에 함유된 탄화수소 함량(C: $42.57 \mathrm{wt} \%, \mathrm{H}$ : $6.58 \mathrm{wt} \%)$ 이 계분에 함유된 탄화수소 함량(C: $29.62 \mathrm{wt} \%, \mathrm{H}: 4.58$ $\mathrm{wt} \%)$ 보다 많기 때문으로 이해된다.

Table 4 에 나타낸 돈분 시험편의 총열방출률(Total heat release rate, $\mathrm{THRR}$ )은 $60.8 \mathrm{MJ} / \mathrm{m}^{2}$ 로 측정되었다. 이에 비하여 계분의 총열방출율 은 $39.7 \mathrm{MJ} / \mathrm{m}^{2}$ 으로 비교적 낮게 나타났다. 또한 돈분과 계분의 혼합 물의 총열방출률은 $41.8 \mathrm{MJ} / \mathrm{m}^{2}$ 로 측정되었다.

총열방출률은 각 실험에서 실험재료의 연소로 인해 방출된 열량 으로서 시료 표면적당 시간에 대한 함수로 표현되는 열방출률을 주어 진 시간으로 적분하여 계산하였다. Table 3에 보여준 바와 같이 무기물 함량이 많은 계분 시편(41.0 wt\%)의 총열방출률은 상대적으로 적은 돈분 시편(8.3 wt\%)에 비교하여 낮았다. 총열방출률은 함유된 무기물 함량 및 무기물 조성에 따라 감소하였다. 이것은 Table 2에서 보여준 바와 같이 $\mathrm{CaO}, \mathrm{P}_{2} \mathrm{O}_{5}, \mathrm{ZnO}, \mathrm{MgO}$ 등의 무기물들이 열안정성 및 연소 억제 효과에 의해 총열방출률이 낮아지는 것으로 설명될 수 있다. 즉, $\mathrm{CaO}$ 는 $277{ }^{\circ} \mathrm{C}$ 미만에서는 물과 반응하여 $\mathrm{Ca}(\mathrm{OH})_{2}$ 를 생성하며 큰열 을 발생하지만[16], 온도가 상승하면 432 452 ${ }^{\circ} \mathrm{C}$ 에서 $\mathrm{Ca}(\mathrm{OH})_{2}$ 가 다 시 분해하여 $\mathrm{CaO}$ 와 $\mathrm{H}_{2} \mathrm{O}$ 를 생성한다[17]. 이후 더 높은 온도에서 생성 된 물은 증발되고 $\mathrm{CaO}$ 는 열안정성을 갖는 것으로 이해된다. 산화아연 $(\mathrm{ZnO})$ 은 $1975{ }^{\circ} \mathrm{C}$ 근처에서 아연 $(\mathrm{Zn})$ 기체와 산소 $\left(\mathrm{O}_{2}\right)$ 로 분해되므로, 상당한 열안정성을 갖으나[18], 난연제로서는 지극히 제한된 효과를 준다[19]. $\mathrm{P}_{2} \mathrm{O}_{5}$ 는 비가연성으로서 연소를 돕지 않고, $\mathrm{MgO}$ 는 화재방벽 역할을 하기 때문으로 이해된다[16]. 시험편의 표면에 대한 외부 열유 속과 화염으로부터의 열유속은 시험편의 열방출률이 최대가 되도록 빨리 도달되게 한 다음, 열분해 전단이 시편의 안쪽으로 이동함에 따 라 숯층이 점진적으로 생성된다. 이 숯층은 외부 열속에 노출된 표면 과 열분해 전단 사이에 증가되는 열적 저항을 형성한다. 결과적으로 최대열방출률이 지속적으로 감소되는 것으로 본 시험결과와 일치한 다[14]. 위 시료의 경우 $\mathrm{CaO}, \mathrm{P}_{2} \mathrm{O}_{5}, \mathrm{ZnO}, \mathrm{MgO}$ 등이 열적 안정성을 가 지고 있어서 이들 시험편의 열적 저항 작용에 대하여 일부 시너지 효
과로 나타나는 것으로 이해된다.

질량감소율은 화재거동에 대하여 추가적인 정보를 준다[15]. Table 4 에 보여준 바와 같이 돈분 시험편의 최대질량감소율(peak mass loss rate, PMLR)은 $0.173 \mathrm{~g} / \mathrm{s}$ 로 측정되었다. 이에 비하여 계분의 최대질량 감소율은 $0.132 \mathrm{~g} / \mathrm{s}$ 로 비교적 낮게 측정되었다. 또한 돈분과 계분 혼합 물의 최대질량감소율은 $0.154 \mathrm{~g} / \mathrm{s}$ 로 측정되었다.

유효연소열은 질량감소율과 함께 물질의 화재거동에 추가적인 정 보를 제공해 주기 위하여 사용될 수 있다. 유효연소열은 한 가지의 분 해 형태를 갖는 균일한 시편의 연소시간 동안의 상수로서 이론적인 순연소열의 값보다 적다[15]. 한 가지 이상의 분해형태를 갖는 재료나 복합재료 또는 비균일한 재료의 유효연소열은 반드시 일정하지는 않 다. Table 4에 나타낸 바와 같이 돈분의 시험편 $(\mathrm{PEHC}=78.72 \mathrm{MJ} / \mathrm{kg}$ ) 과 무기물 함량이 많은 계분의 시험편 $(\mathrm{PEHC}=69.41 \mathrm{MJ} / \mathrm{kg})$ 의 최대 유효연소열은 차별성이 있다.

질량감소율(mass loss rate, MLR)과 유효연소열(effective heat of combustion, EHC)은 열방출률(HRR) 의 함수이며, 다음과 같은 식 (3) 으로 설명되어진다[14].

$$
\text { - } Q(H R R)=\dot{m} \cdot \Delta h_{c}
$$

여기에서 · $\mathrm{Q}(\mathrm{kW})=$ 열방출률, $\mathrm{m}(\mathrm{kg} / \mathrm{s})=$ 질량감소율, $\Delta \mathrm{h}_{\mathrm{c}}(\mathrm{kJ} / \mathrm{kg})$ $=$ 유효연소열로 표된다. 즉, 질량감소율과 유효연소열은 열방출률의 함수 관계가 된다.

\section{2. 연소 생성물 평가}

Table 4에 나타낸 바와 같이 돈분 시험편의 $\mathrm{CO}_{\text {mean }}$ 가스 발생량은 $0.0827 \mathrm{~kg} / \mathrm{kg}$ 으로 측정되었다. 이에 비하여 계분 시험편의 $\mathrm{CO}_{\text {mean }}$ 가 스의 평균 발생량은 $0.0996 \mathrm{~kg} / \mathrm{kg}$ 으로서 돈분 시험편에 비하여 약간 높게 나타났다. 또 이것에 대하여 연소시간 측면에서 고려한 $\mathrm{CO}$ 발생 속도는 Figure 2에서 보여준 바와 같다. 돈분 시험편은 착화 후 $337 \mathrm{~s}$, $394 \mathrm{~s}$ 에서 각각 $0.0027 \mathrm{~g} / \mathrm{s}, 0.0028 \mathrm{~g} / \mathrm{s}$ 의 최대 $\mathrm{CO}$ 발생속도를 나타내 었다. 또 계분 시험편은 $365 \mathrm{~s}$ 에서 가장 높은 $\mathrm{CO}$ 발생속도 $(0.0034 \mathrm{~g} / \mathrm{s})$ 를 나타내었다. 혼합물 시험편은 $296 \mathrm{~s}$ 에서 $0,0033 \mathrm{~g} / \mathrm{s}$ 의 CO 최대 발 생속도를 보였다. 이와 같이 계분의 $\mathrm{CO}_{\text {mean }}$ 발생량 및 최대의 $\mathrm{CO}$ 발 생속도가 높은 것은 앞서 설명된 바와 같이 계분에 포함된 무기물 함 량(41.0 wt\%)이 돈분에 포함된 무기물 함량 $(8.3 \mathrm{wt} \%)$ 보다 크기 때문 에, 이들 무기물 성분들이 탄화수소의 연소억제 작용을 효과적으로 하는 것으로 판단된다.

Table 4에 나타낸 바와 같이 돈분 시험편의 $\mathrm{CO}_{2 \text { mean }}$ 발생량은 2.11 $\mathrm{kg} / \mathrm{kg}$ 로 측정되었다. 계분 시험편에서 $\mathrm{CO}_{2 \text { mean }}$ 발생량은 $2.31 \mathrm{~kg} / \mathrm{kg}$ 으 


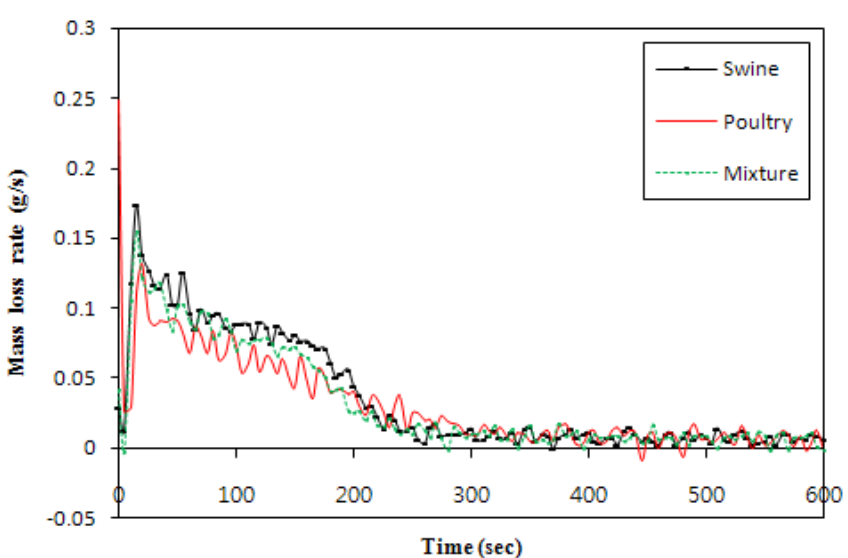

Figure 1. Mass loss rate curves to time of the specimens of the swine manure, poultry manure, and mixture at $50 \mathrm{~kW} / \mathrm{m}^{2}$ extemal heat flux.

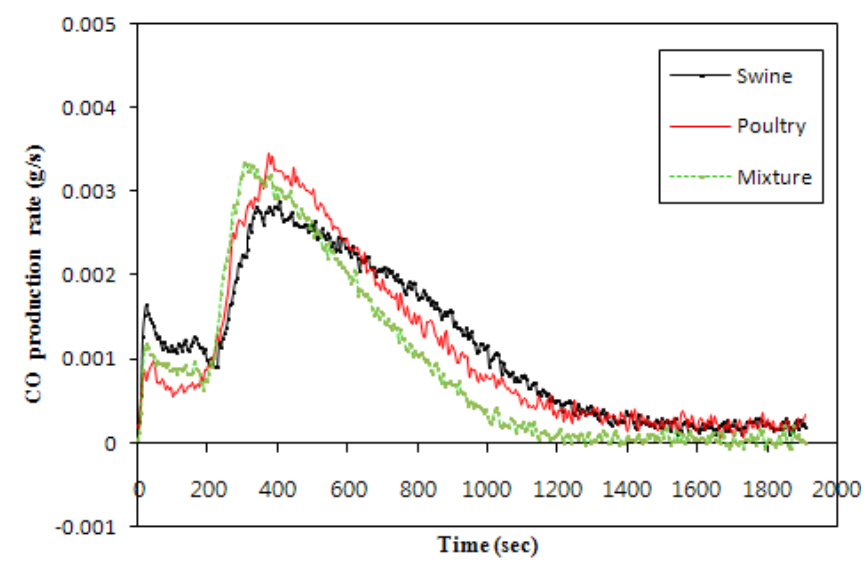

Figure 2. CO production rate curves to time of the specimens of the swine manure, poultry manure, and mixture at $50 \mathrm{~kW} / \mathrm{m}^{2}$ extemal heat flux.

로서 돈분 시험편의 $\mathrm{CO}_{2 \text { mean }}$ 발생량과 비하여 약간 높게 나타났으나 특별한 차별성을 구분하기는 어렵다. 또 이것에 대하여 연소시간 측 면에서 고려한 $\mathrm{CO}_{2}$ 발생속도는 Figure 3에 보여준 바와 같다. 시험편 의 착화 후 돈분 시험편은 $13 \mathrm{~s}$ 에서 급격한 상승의 $\mathrm{CO}_{2}$ 발생속도 $(0.1959$ $\mathrm{g} / \mathrm{s}$ ) 커브를 보였다. 계분 시험편은 $14 \mathrm{~s}$ 에서 $0.0121 \mathrm{~g} / \mathrm{s}$ 으로 낮게 나타 났다. 이것은 무기물 성분에 의한 연소억제 효과에 의하여 $\mathrm{CO}_{2}$ 발생 속도를 감소시키는 것으로 판단된다. 또 $\mathrm{CO} / \mathrm{CO}_{2}$ 에 대하여 Table 4에 나타낸 바와 같이 돈분 시험편의 경우 0.0391 에 비하여, 계분 시험편 에서는 0.0431 로 나타났다. 또 혼합물은 0.0410 으로 나타났다. 이것은 앞서 설명한 $\mathrm{CO}_{\text {mean }}$ 발생량의 경향과 일치된다.

총연기발생률(total smoke release rate, TSRR)에 대하여 Table 4에 나타낸 바와 같이 돈분 시험편의 총연기발생률은 $419 \mathrm{~m}^{2} / \mathrm{m}^{2}$ 로 측정되 었다. 이에 비하여 계분 시험편의 총연기발생률은 $83.3 \mathrm{~m}^{2} / \mathrm{m}^{2}$ 으로 나 타났다. 또 혼합물은 $314.7 \mathrm{~m}^{2} / \mathrm{m}^{2}$ 으로서 돈분 시험편의 총연기발생률 에 비하여 비교적 낮게 나타났다. 이것에 대하여 연소시간 측면에서 고려한 총연기발생률을 Figure 4에 보였다. 시험편의 착화 후 약 $200 \mathrm{~s}$ 근처에서 급격한 상승커브를 나타내었다. 이것은 시험편의 무기물 함 량에 의한 연소억제 효과로 연기발생이 감소되는 것으로 판단된다 [18-21].

연기량은 빛 흡수에 의해 콘칼로리미터에서 측정되기 때문에 그것

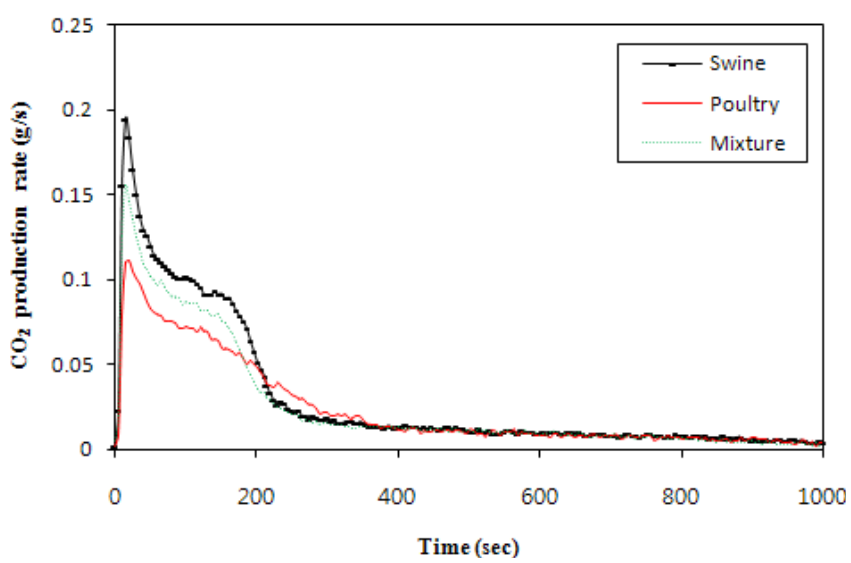

Figure 3. $\mathrm{CO}_{2}$ production rate curves to time of the specimens of the swine manure, poultry manure, and mixture at $50 \mathrm{~kW} / \mathrm{m}^{2}$ extemal heat flux.

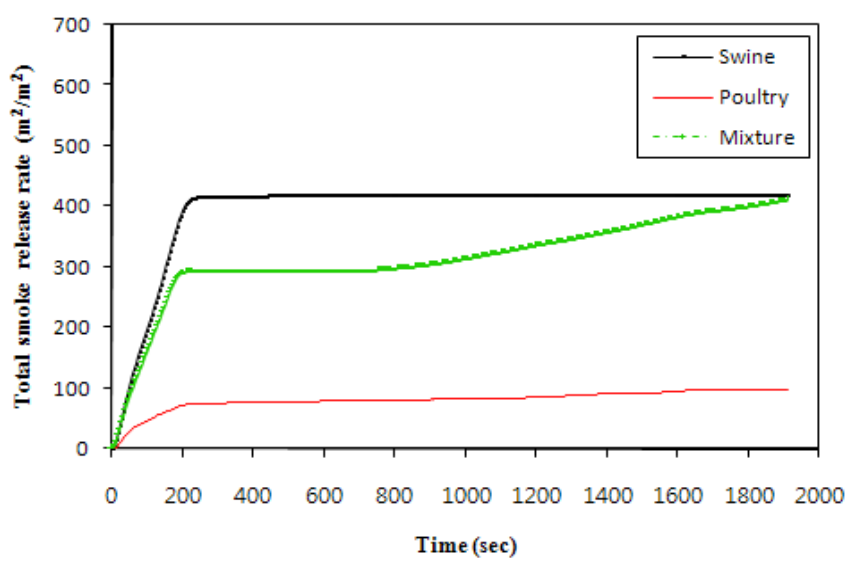

Figure 4. Total smoke release rate curves to time of the specimens of the swine manure, poultry manure, and mixture at $50 \mathrm{~kW} / \mathrm{m}^{2}$ extemal heat flux.

은 액체입자(타르), 증기, 무기입자, 탄소를 포함한 입자들이 나타날 수 있다. 이 연기는 불꽃연소에서 형성되고 가연물의 열분해로부터 생성된 가연성가스는 불꽃 영역 내에 숮을 생성하는 다환성 방향족 탄화수소로 구성된다. 그리고 타지 않은 숮은 불꽃을 냉각시키는 원 인이 되며 불꽃 영역으로부터 불완전연소를 만드는 연기로 된다[22]. 돈분 시편의 연기 생성 거동은 열방출 영역에서 연기가 생성되었으며, 열방출률이 높은 곳에서 연기 발생 속도가 초기 연기 생성 속도보다 5 배 정도 증가하였다.

\section{4. 결 론}

돈분, 계분, 혼합물 시험편의 연소특성에 관한 실험을 ISO 5660-1 표준에 따른 콘칼로리미터를 이용하여 수행하였으며, 다음과 같은 결 론을 얻었다.

1) $50 \mathrm{~kW} / \mathrm{m}^{2}$ 의 외부열원에서 시험한 결과 돈분 시험편의 최대유효 연소열 $\left(\mathrm{EHC}_{\mathrm{peak}}\right)$ 은 $78.72 \mathrm{MJ} / \mathrm{kg}$ 로 나타났으며, 계분 시험편은 69.41 $\mathrm{MJ} / \mathrm{kg}$ 으로 나타났다. 또 혼합물은 $71.62 \mathrm{MJ} / \mathrm{kg}$ 으로 나타났다. 이것은 돈분에 함유된 탄화수소 함량이 계분에 함유된 탄화수소 함량보다 높 기 때문으로 이해된다. 따라서 높은 연소 에너지는 탄화수소의 함량 에 의존하여 발생된다. 
2) $\mathrm{CO}_{\text {mean }}$ 발생량 및 $\mathrm{CO}$ 발생속도는 돈분 시험편에 대하여 각각 $0.0827 \mathrm{~kg} / \mathrm{kg}$ 및 $0.0027 \sim 0.0028 \mathrm{~g} / \mathrm{s}$ 에 비교하여, 계분 시험편은 각각 $0.0996 \mathrm{~kg} / \mathrm{kg}$ 및 $0.0034 \mathrm{~g} / \mathrm{s}$ 으로 다소 증가하였다. 이것은 돈분에 포함 된 무기물함량 $(8.3 \mathrm{wt} \%)$ 에 비하여 계분에 포함된 많은 무기물 함량 $(41.0 \mathrm{wt} \%)$ 및 구성 성분들이 탄화수소의 연소억제 작용을 효과적으 로 하기 때문으로 판단된다. 또한 총연기발생률도 이와 유사한 경향 을 보였다.

3) $\mathrm{CO}_{2}$ 의 초기 발생속도는 계분 시험편의 $0.1554 \mathrm{~g} / \mathrm{s}$ 에 비교하여 돈 분 시험편은 $0.1959 \mathrm{~g} / \mathrm{s}$ 로서 다소 증가하였다. 이것은 앞에서 언급한 최대유효연소열에 대한 설명과 같은 맥락으로 분뇨 조성 중 가연성 탄화수소의 함량에 의존하는 것으로 이해된다.

4) 따라서 이러한 실험결과들은 축산분뇨 처리의 재활용에 의한 재 생 에너지화에 유용하게 사용될 수 있으며, 이후 기타 다른 가연성 폐 기물과의 혼합 연소에 의한 에너지 효율성에 대하여 확대 검토해야 할 것으로 판단된다.

\section{감 사}

본 연구는 2013년도 강원대학교 학사경비보조금 재원으로 수행되 었습니다.

\section{참 고 문 헌}

1. Ministry of Environment, Energy-Independent Rural Town Planning, Ministry of Environment (2009).

2. Ministry of Agriculture Forestry Fisheries and Food, Dumping Manure on the Ocean Is to Completely Stop That From 1 January Each year, Ministry of Agriculture Forestry Fisheries and Food (2011).

3. B. K. Ranjian, Sustainable urban energy-environment management with multiple objectives, The Journal of Energy., 21, 305 (1996).

4. S. C. Hwang, Optimization System Research for Bio-Gas Production Using Manure to Comply with the Domestic Conditions, Ministry of Agriculture and Food (2006).

5. Policy Department of Food, Agriculture, Forestry and Fisheries and Livestock, Recycling of livestock Manure and Efficient Management Practices, Ministry of Agriculture and Food (2010).

6. C. H. Kim, Energy Plan using Resource Recycling Manure, 2011 Natural Eco-farming Process, Agricultural Research and Training Institute, Ministry of Agriculture and Food (2011).

7. V. Babrauskas, New Technology to Reduce Fire Losses and Costs. eds. S. J. Grayson and D. A. Smith. Elsevier Appied Science
Publisher, London, UK (1986).

8. M. M. Hirschler, Thermal Decomposition and Chemical Composition, American Chemical Society Symposium Series, 797 (2001).

9. ISO 5660-1. Reaction-to-Fire Tests-Heat Release, Smoke Production and Mass Loss Rate-Part 1: Heat Release Rate (Cone Calorimeter Method), Genever (2001).

10. I. G. Jeon, Mater Dissertation, Kangwon National University, Gangwon, Korea (2013).

11. Y. J. Chung, Comparison of combustion properties of native wood species used for fire pots in korea, J. Ind. Eng. Chem., 16, 15-19 (2010).

12. F. M. Pearce, Y. P. Khanna, and D. Raucher, Thermal Analysis in Polymer flammability, Chap. 8, Thermal Characterization of Polymeric Materials, Academic Press, New York, U.S.A. (1981).

13. J. D. DeHaan, Kirks's Fire Investigation, Fifth Edition, 84. Prentice Hall, New Jersey, U.S.A. (2002).

14. V. Babrauskas and S. J. Grayson, Heat Release in Fires. E \& FN Spon (Chapman and Hall), London, UK (1992).

15. V. Babrauskas, Heat Release Rate, Section 3, The SFPE Handbook of Fire Protection Engineering, Fourth ed., National Fire Protection Association. Massatusetts, U.S.A. (2008).

16. Martha Windholz, THE MERK INDEX, Tenth Edition, Merk \& Co. Inc., Pahway, New Jersey, U.S.A. (1983).

17. D. Alonso, F. Martin. R. Vila. M. Mariscal, and M. Ojeda, Lopez Granados., and J. Santamaria-Gonzallez, Relevance of the physicochemical properties of $\mathrm{CaO}$ catalysts for the methanolysis of triglycerides to obtain biodiesel, Catalysis Today, 158, 114-120 (2010).

18. N. N. Greenwood and A. Earnshow, Chemistry of Elements, Butterworth-Heinemann, Oxford, UK (1997).

19. M. M. Hirscher, Reduction of smoke formation from and flammability of thermoplastic polymers by metal oxides, Polymer, 25, 405-411 (1984).

20. J. Zhang, D. D. Jiang, and C. A. Wilkie, Thermal and flame properties of polyethylene and polypropylene nanocomposites based on an oligomerically-modified clay, Polm. Degrad. Stab., 91, 298-304 (2006).

21. Y. J. Chung, H. M. Lim, E. Jin, and J. K. Oh, Combustion-retardation properties of low density polyethylene and ethylene vinyl acetate mixtures with magnesium hydroxide, Appl. Chem. Eng., 22, 439-443 (2011).

22. Y. J. Chung, Comparison of combustion properties of the pinus rigida, castanea savita, and zelkova serrata, J. Korean Instiute of Fire Sci. Eng., 23, 73 (2009). 